\title{
Hubungan antara Persepsi Keterlibatan Ayah dalam Proses Pengasuhan dengan Kecerdasan Emosional pada Remaja
}

WIWID NUR ISLAMI \& NUR AINY FARDANA N.*

Departemen Psikologi Pendidikan dan Perkembangan, Fakultas Psikologi Universitas Airlangga

\begin{abstract}
ABSTRAK
Penelitian ini bertujuan untuk mengetahui apakah terdapat hubungan antara keterlibatan ayah dalam pengasuhan dengan kecerdasan emosional pada remaja. Penelitian ini dilakukan pada remaja berusia 13-18 tahun dengan jumlah subjek sebanyak 238 orang, yang terdiri dari laki-laki sebanyak 76 orang dan perempuan sebanyak 162 orang. Alat pengumpulan data yang digunakan yaitu kuesioner skala persepsi keterlibatan ayah dalam pengasuhan dan skala kecerdasan emosional. Analisis data dilakukan dengan teknik korelasi Pearson's Product Moment dengan bantuan program SPSS 24.0 for Windows. Hasil analisis menunjukkan bahwa nilai signifikansi yang diperoleh yaitu 0,000 dengan nilai korelasi sebesar 0,389. Hal ini menunjukkan bahwa terdapat hubungan yang signifikan dengan arah positif. Artinya, semakin tinggi persepsi keterlibatan ayah dalam pengasuhan, maka semakin tinggi juga kecerdasan emosional pada remaja.
\end{abstract}

Kata kunci: kecerdasan emosional, keterlibatan ayah dalam pengasuhan, remaja

\section{ABSTRACT}

This study aims to determine whether there is a relationship between the involvement of fathers in parenting and emotional intelligence in adolescents. This research was conducted on adolescents aged 13-18 years with 238 subjects, consisting of 76 men and 162 women. Data collection tools used were a questionnaire on the scale of the perception of fathers' involvement in parenting and the scale of emotional intelligence. Data analysis was performed using Pearson's Product Moment correlation technique with the help of the SPSS 24.0 for Windows program. The results of the analysis show that the significance value obtained is 0.000 with a correlation value of 0.389 . This shows that there is a significant relationship with a positive direction. This means that the higher the perception of the involvement of the father in parenting, the higher the emotional intelligence of adolescents.

Keywords: adolescence, emotional intelligence, father involvement

Buletin Penelitian Psikologi dan Kesehatan Mental (BRPKM), 2021, Vol. 1(1), 317-326

*Alamat korespondensi: Fakultas Psikologi Universitas Airlangga, Kampus B Universitas Airlangga Jalan Airlangga 4-6 Surabaya 60286. Surel: nurainy.fardana@psikologi.unair.ac.id

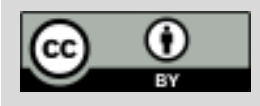

Naskah ini merupakan naskah dengan akses terbuka dibawah ketentuan the Creative Common Attribution License (CC-BY-4.0) (http://creativecommons.org/licenses/by/4.0), sehingga penggunaan, distribusi, reproduksi dalam media apapun atas artikel ini tidak dibatasi, selama sumber aslinya disitir dengan baik. 


\section{PEN D A H U L U A N}

Masa remaja adalah periode transisi yang menghubungkan antara masa kanak-kanak menuju masa dewasa (Santrock, 2014). Hidayati dan Farid (2016) juga menambahkan bahwa pada masa remaja ini terdapat beberapa pertumbuhan dan perkembangan yang terjadi baik secara biologis, maupun psikologis. Artinya, pada masa ini, mereka tidak dapat dikatakan sebagai seseorang yang dewasa namun juga tidak sebagai seorang anak-anak.

Dalam proses pencarian jati diri, para remaja sering kali dituntut untuk bisa mengambil keputusan secara mandiri di lingkungannya, sedangkan selama masa kanak-kanak pola pengasuhan yang diberikan tidak menekankan kepada kemampuan mengambil keputusan secara mandiri sehingga menyebabkan ketidaksiapan remaja dalam menghadapi kondisi barunya tersebut. Ketidaksiapan inilah dapat mengakibatkan adanya ketidakstabilan emosi pada diri remaja sebagai akibat dari usaha penyesuaian dirinya terhadap tekanan sosial dan kondisi yang baru (Hurlock, 2004). Perubahan emosi inilah membuat remaja seringkali berada pada pada kondisi yang labil dan rentan dalam mengendalikan emosi sehingga seringkali memunculkan perilaku yang beresiko.

Apabila remaja mengalami situasi yang tidak menyenangkan atau mendapatkan sesuatu yang tidak disenangi, maka remaja tersebut akan lebih cenderung menyelesaikan dengan emosi yang negatif bahkan agresif (Illlahi, Neviyarni, Said, \& Ardi, 2018). Menurut Guswani \& Kawuryan (2011) faktorfaktor yang mempengaruhi perilaku agresif antara lain kematangan emosi, kontrol diri, religiusitas, kecerdasan emosional dan pengaruh media. Dalam hal ini, salah satu faktor yang mempengaruhi perilaku agresif adalah kecerdasan emosional.

Sejalan dengan hal itu, terdapat penelitian dari Agung \& Matulessy (2012) yang didapatkan hasil bahwa kecerdasan emosional berkorelasi negatif dengan perilaku agresif. Hal tersebut menunjukkan bahwa remaja yang menunjukkan perilaku agresif yang tinggi diakibatkan oleh kecerdasan emosional yang rendah dan sebaliknya remaja yang menunjukkan perilaku agresif rendah diakibatkan oleh kecerdasan emosional yang tinggi. Dengan kata lain, kecerdasan emosional memiliki hubungan dengan perilaku agresif yang dilakukan oleh remaja.

Penelitian yang dilakukan oleh Pacheco \& Berrocal (2004) menunjukkan hasil bahwa kecerdasan emosional yang rendah pada remaja dapat menyebabkan penurunan kuantitas serta kualitas hubungan dengan orang lain, penurunan dalam bidang akademik, dan dapat memunculkan perilaku agresi maupun kenakalan. Perilaku agresif atau perilaku bermasalah yang ditunjukkan remaja menunjukkan bahwa individu tidak mampu mengendalikan emosi yang muncul dalam dirinya.

Adapun kasus yang terjadi di kalangan remaja yang berkaitan dengan rendahnya kecerdasan emosional yaitu seorang siswa SMA melakukan penganiayaan terhadap gurunya sendiri. Penganiayaan tersebut terjadi karena guru yang bersangkutan mencolek pipi siswanya dengan cat warna karena siswa tersebut mengganggu teman-temannya saat pelajaran. Kasus penganiayaan terhadap guru tersebut berujung pada kematian. Salah satu faktor penyebab yang ditulis dalam berita tersebut adalah siswa cenderung memiliki kepribadian yang impulsif dan mengalami kesulitan mengendalikan emosi (Damhuri, 2018).

Berdasarkan kasus tersebut, seseorang yang tidak mampu mengendalikan atau mengatur emosinya dengan baik dapat menunjukkan perilaku yang impulsif. Kasus tersebut tidak hanya terjadi pada seorang siswa terhadap guru ataupun seorang siswa terhadap aparatur pemerintah melainkan juga dapat terjadi antara siswa dengan teman sebaya. Seperti yang dilaporkan oleh KPAI bahwa terdapat 41 kasus anak yang menjadi pelaku kekerasan dan pelaku perundungan pada tahun 2018 (Pratama, 2018). 
Selain itu, berdasarkan laporan dari UNICEF, 50\% anak di Indonesia pernah menjadi korban perundungan di sekolah (UNICEF, 2015).

Menurut Salovey, menjelaskan bahwa seseorang yang cerdas secara emosional akan mengerti dan memahami kondisi emosinya sendiri sehingga mampu untuk menyelesaikan masalah yang terjadi pada dirinya (Matthews, Zeidner, \& Roberts, 2002). Selanjutnya, Goleman D. (2009) juga menambahkan bahwa individu yang paham secara emosional, akan mampu mengetahui perasaannya, dan mampu memahami serta menghargai perasaan orang lain.

Adapun faktor pembentuk kecerdasan emosional salah satunya berasal dari faktor keluarga. Goleman D. (2009) mengatakan bahwa adalah lingkungan pertama bagi individu untuk belajar memahami apa yang dirasakan dan bagaimana orang lain akan memberi respon terhadap emosi, bagaimana mengenali perasaan mereka dan bagaimana bereaksi terhadap perasaan tersebut, serta bagaimana cara membaca dan mengekspresikan emosi. Oleh karena itu, pembelajaran emosi yang diterima anak tidak hanya melalui apa yang diucapkan atau dilakukan orang tua secara langsung, melainkan juga bagaimana orang tua saat menangani perasaannya sendiri (Wulandari, 2012).

Penelitian yang dilakukan oleh Asghari \& Besharat (2011) menjelaskan bahwa perkembangan kecerdasan emosional pada remaja dipengaruhi oleh pengasuhan ayah dan ibu serta persepsi anak terkait pengasuhan tersebut. Artinya, orangtua memiliki pengaruh terhadap perkembangan kecerdasan emosional pada remaja. Namun, pada kenyataannya ibu lebih memiliki peran andil dalam mendidik dan mengasuh anak, sedangkan ayah memiliki tugas untuk mencukupi kebutuhan anggota keluarga termasuk anak. Dalam hal ini, ayah tidak memiliki peran yang cukup tinggi dalam mendidik dan mengasuh anak. Padahal seharusnya dalam pengasuhan anak perlu melibatkan peran ayah didalamnya, hal ini dikarenakan perkembangan seorang anak hingga dewasa nantinya akan dipengaruhi oleh pengalaman-pengalaman yang dilalui bersama ayah (Setyawati \& Rahardjo, 2015).

Berdasarkan penjelasan di atas, diketahui bahwa tidak hanya ibu yang memiliki pengaruh terhadap perkembangan anak khususnya perkembangan emosional, akan tetapi ayah juga memiliki pengaruh dalam pengasuhan tersebut. Hal ini berdasar pada penelitian Hunter, dkk. (2011) yang menunjukkan bahwa keterlibatan ayah dalam pengasuhan dapat membantu individu untuk lebih mampu menerima emosi negatif yang dirasakan pada peristiwa-peristiwa yang mengecewakan. Allen \& Daly (2007) juga menyebutkan bahwa keterlibatan ayah dapat membantu remaja untuk mengurangi perilaku menyimpang atau negatif, agresifitas dan dapat mengurangi konflik yang terjadi pada masa remaja.

Keterlibatan ayah dalam pengasuhan remaja dapat dilihat atau dipahami melalui pandangan remaja terhadap bagaimana peran ayah dalam pengasuhan dirinya. Remaja yang merasakan keterlibatan ayah dalam mengasuh dirinya, akan mempersepsikan keterlibatan ayahnya secara positif (Handayani \& Kustanti, 2018). Dalam hal ini, persepsi dapat mempengaruhi pembentukan sikap dan perilaku anak terhadap orang tua. Finley \& Schwartz (2004) mengatakan bahwa penelitian tentang keterlibatan ayah tidak hanya berada pada jumlah waktu yang dihabiskan bersama remaja, akan tetapi juga melihat bagaimana persepsi remaja tentang keterlibatan ayah dalam pengasuhan tersebut.

Berdasarkan penjelasan diatas, peneliti tertarik untuk mengetahui apakah terdapat hubungan antara persepsi keterlibatan ayah dalam pengasuhan dengan kecerdasan emosional pada remaja.

\section{Kecerdasan Emosional}

Kecerdasan emosional atau emotional intelligence adalah suatu bentuk kemampuan seseorang akan kesadaran dirinya dalam mengelola emosi dan menghadapi tekanan, mengontrol emosi dan 
meregulasinya, mampu memahami perasaan orang lain serta menjalin hubungan interpersonal (Goleman D., 2007). Mayer, Salovey dan Caruso (2008) menambahkan bahwa kemampuan untuk memahami emosi diri maupun orang lain dapat membantu individu untuk bersikap dan berperilaku.

Kecerdasan emosional memiliki beberapa aspek-aspek tertentu yang membentuknya. Adapun aspek aspek kecerdasan emosional menurut Goleman (2007), diantaranya sebagai berikut:

a. Mengenal emosi diri atau kesadaran diri, yaitu proses mengenali perasaan yang sedang dialami.

b. Mengelola emosi, yaitu kemampuan untuk mengontrol emosi seseorang agar tidak lepas kendali.

c. Memotivasi diri sendiri, berkaitan dengan pengendalian diri emosional yaitu kemampuan seseorang untuk menahan diri dalam melakukan sesuatu.

d. Mengenali emosi orang lain (empati), yaitu individu yang memiliki kemampuan empati lebih mampu untuk memahami emosi yang dirasakan oleh orang lain serta peka terhadap apa yang terjadi dengan orang lain.

e. Membina hubungan, dalam hal ini keterampilan sosial dalam kecerdasan emosional akan menumbuhkan hubungan sosial yang baik antara dua orang atau lebih.

\section{Keterlibatan Ayah dalam Proses Pengasuhan}

Keterlibatan ayah dalam pengasuhan menurut Lamb (2010) merupakan keterlibatan ayah yang terlibat langsung dalam mendukung perkembangan anak, yang di dalamnya terdapat aspek-aspek seperti interaksi, memberikan kehangatan, pemantau aktivitas anak serta bertanggung jawab terhadap kebutuhan anak.

Lamb (2010) menguraikan dimensi-dimensi keterlibatan ayah dalam pengasuhan sebagai berikut:

a. Engagement, merupakan interaksi antara ayah dan anak secara langsung melalui pengasuhan sehari-hari dan aktivitas yang dilakukan bersama-sama seperti bermain, mengajari sesuatu atau aktivitas santai lainnya.

b. Accessibility, merupakan bentuk pengasuhan yang menggambarkan bagaimana kehadiran atau ketersediaan ayah tanpa adanya interaksi secara langsung.

c. Responsibility, merupakan bentuk keterlibatan ayah yang meliputi tanggung jawab untuk mengurus dan memenuhi kebutuhan anak.

\section{E T O D E}

\section{Desain Penelitian}

Tipe penelitian yang digunakan dalam penelitian ini adalah penelitian kuantitatif. Penelitian kuantitatif adalah penelitian yang disertai data dan analisis berupa statistik. Penelitian ini menggunakan teknik survey, yaitu dengan membagikan link kuesioner penelitian kepada subjek sebagai bagian dari populasi yang ada. Penelitian ini termasuk ke dalam jenis penelitian korelasional. Penelitian korelasional merupakan penelitian yang melihat sejauh mana variabel satu berkaitan dengan variabel lainnya (Azwar, 2012).

\section{Partisipan}

Kriteria pemilihan partisipan yang digunakan dalam penelitian ini yaitu remaja berusia 13-18 tahun, tinggal satu rumah dengan ayah dan ibu, serta Memiliki jenis kelamin laki-laki atau perempuan. Adapun teknik pengambilan sampel menggunakan metode nonprobability sampling dengan teknik purposive 
sampling. Nonprobability sampling merupakan metode pengambilan sampel dimana tidak semua anggota pada populasi memiliki kesempatan yang sama untuk dijadikan sampel penelitian. Sedangkan teknik purposive sampling digunakan dalam penelitian ini karena peneliti melakukan pengambilan sampel atas pertimbangan tertentu yang sesuai dengan karakteristik yang dibutuhkan.

\section{Pengukuran}

Skala yang digunakan untuk mengukur persepsi keterlibatan ayah dalam proses pengasuhan dalam penelitian ini menggunakan skala alat ukur keterlibatan ayah yang disusun oleh Puspitorini (2016) dengan mengacu pada teori milik Lamb (2010) yang meliputi 3 dimensi yaitu engagement, accessibility, dan responsibility. Skala ini terdiri dari 44 aitem dengan menggunakan 5 pilihan jawaban $(1=$ "sangat tidak setuju", 2= "tidak setuju", 3= "netral", 4= "setuju", 5= "sangat setuju"). Skala ini memiliki nilai reliabilitas $(\alpha=0,969)$. Selain itu, skala yang digunakan untuk mengukur kecerdasan emosional yaitu menggunakan skala alat ukur yang disusun oleh Hardanti (2020) berdasarkan teori yang dikemukakan oleh Goleman (2007) yang meliputi 5 aspek yaitu, mengenali emosi diri, mengelola emosi, memotivasi diri, mengenal emosi orang lain serta membina hubungan. Skala ini terdiri dari 60 aitem dengan menggunakan 4 pilihan jawaban (1= "sangat tidak sesuai", $2=$ "tidak sesuai", 3= "sesuai", 4= "sangat sesuai”. Skala kecerdasan emosional memiliki nilai reliabilitas $(\alpha=0,915)$.

\section{Analisis Data}

Analisis data adalah proses untuk mengolah dan mengorganisasikan data yang telah didapatkan sebelumnya sehingga dapat dibaca dan diinterpretasikan (Azwar, 2012). Teknik analisis data yang digunakan dalam penelitian ini adalah uji korelasi parametrik dengan teknik korelasi Pearson Product Moment dengan bantuan program SPSS 24.0 for Windows.

\section{HAS I L P E N EL I T IAN}

Hasil analisis deskriptif menunjukkan bahwa mayoritas partisipan memiliki kecerdasan emosional dengan kategori sedang yaitu sebanyak 164 orang $(68,9 \%)$, kategori rendah sebanyak 35 orang $(14,7 \%)$, dan kategori tinggi sebanyak 39 orang $(16,4 \%)$. Selain itu, hasil penelitian juga menunjukkan bahwa mayoritas partisipan memiliki persepsi keterlibatan ayah dalam pengasuhan dengan kategori sedang yaitu sebanyak 178 orang $(74,8 \%)$, kategori rendah sebanyak 28 orang $(11,8 \%)$, dan kategori tinggi sebanyak 32 orang $(13,4 \%)$.

Selanjutnya, setelah melakukan hasil uji analisis statistik deskriptif peneliti melakukan uji asumsi normalitas dan uji asumsi linearitas. Berdasarkan uji normalitas, diketahui bahwa nilai signifikansi yang diperoleh antara variabel persepsi keterlibatan ayah dalam pengasuhan dan kecerdasan emosional yaitu sebesar 0,097 ( $p>0,05$ ) yang artinya data berdistribusi normal. Berdasarkan uji linearitas, diketahui bahwa variabel persepsi keterlibatan ayah dalam pengasuhan dan kecerdasan emosional memiliki hubungan yang linear $(\mathrm{p}=0,000)$.

Berdasarkan uji asumsi yang telah dilakukan yaitu uji normalitas dan uji linearitas, didapatkan hasil bahwa data penelitian dari skala persepsi keterlibatan ayah dalam proses pengasuhan dan kecerdasan emosional memiliki sebaran data yang normal dan memiliki hubungan yang linear. Selanjutnya, uji analisis statistik yang digunakan yaitu menggunakan statistik parametrik dengan teknik korelasi Pearson Product Moment. Teknik ini bertujuan untuk mengetahui suatu hubungan dan arah hubungan dari kedua variabel yang diteliti. Berdasarkan hasil uji korelasi Pearson Product Moment, diketahui bahwa persepsi keterlibatan ayah dalam proses pengasuhan dengan kecerdasan emosional berkorelasi 
positif dan memiliki nilai koefisien korelasi sebesar 0,389 yang menunjukkan bahwa kekuatan korelasi sedang. Selain itu, nilai signifikansi yang diperoleh sebesar $0,000(p<0,05)$ yang artinya terdapat hubungan antara persepsi keterlibatan ayah dalam proses pengasuhan dengan kecerdasan emosional pada remaja.

\section{I S K U S I}

Hasil analisis pada penelitian ini menunjukkan bahwa terdapat hubungan antara persepsi keterlibatan ayah dalam proses pengasuhan dengan kecerdasan emosional pada remaja, yang artinya adalah ketika keterlibatan ayah tinggi dalam proses pengasuhan, maka kecerdasan emosional yang dimiliki oleh remaja juga akan tinggi. Hasil dalam penelitian ini juga mendukung temuan penelitian yang telah dilakukan sebelumnya oleh Dewi dan Kristiana (2017) yang menjelaskan bahwa persepsi keterlibatan ayah dalam pengasuhan memiliki hubungan dengan kecerdasan emosional dimana kedua hubungan tersebut menunjukkan arah positif yang berarti menunjukkan semakin tinggi keterlibatan ayah dalam pengasuhan maka semakin tinggi pula kecerdasan emosional pada remaja dan sebaliknya.

Kecerdasan emosional merupakan kemampuan yang dapat dipelajari dan dikembangkan (Zeidner, Matthew, \& Roberts, 2009). Untuk mengembangkan kecerdasan emosional pada remaja dapat dilakukan oleh berbagai pihak, salah satunya adalah lingkungan keluarga. Penelitian yang dilakukan oleh Asghari dan Besharat (2011) menjelaskan bahwa perkembangan kecerdasan emosional pada remaja dipengaruhi oleh pengasuhan ayah dan ibu serta persepsi anak terkait pengasuhan tersebut.

Persepsi terhadap keterlibatan ayah dalam pengasuhan merupakan penilaian tentang seberapa besar peran ayah dalam melakukan pengasuhan terhadap remaja. Terkadang apa yang dianggap baik oleh ayah dan diterapkan pada remaja, justru terkadang dianggap sebagai hal yang sebaliknya. Oleh karena itu, seorang ayah perlu mengetahui dan memahami karakteristik remaja agar dapat menyesuaikan cara pengasuhan yang tepat diterapkan pada remaja. Ketika remaja memberikan respon yang baik terhadap ayah, dapat dimaknai bahwa remaja memiliki persepsi yang positif terhadap keterlibatan ayah dalam pengasuhan. Begitupun sebaliknya, ketika remaja memberikan respon negatif terhadap ayah, dapat dimaknai bahwa remaja memiliki persepsi yang negatif terhadap keterlibatan ayah dalam pengasuhan.

Hasil dalam penelitian ini juga mendukung temuan penelitian yang telah dilakukan sebelumnya oleh Dewi dan Kristiana (2017) yang menjelaskan bahwa persepsi keterlibatan ayah dalam pengasuhan memiliki hubungan dengan kecerdasan emosional dimana kedua hubungan tersebut menunjukkan arah positif yang berarti menunjukkan semakin tinggi keterlibatan ayah dalam pengasuhan maka semakin tinggi pula kecerdasan emosional pada remaja, dan sebaliknya semakin rendah keterlibatan ayah dalam pengasuhan, maka semakin rendah kecerdasan emosional pada remaja.

Aspek yang paling tinggi dipersepsikan oleh remaja terkait keterlibatan ayah dalam pengasuhan dengan kecerdasan emosional yaitu terletak pada aspek responsibility. Responsibility merupakan bentuk keterlibatan ayah yang meliputi tanggung jawab untuk mengurus dan memenuhi kebutuhan anak. Pada aspek ini juga berkaitan dengan bagaimana seorang ayah mengontrol anaknya, melakukan perencanaan dan melakukan pengambilan keputusan bersama anak. Menurut Partasari dkk, (2017) ayah yang terlibat dalam mengontrol anaknya, biasanya ditampilkan dalam bentuk menentukan peraturan dan memantau kegiatan anak. Menentukan peraturan misalnya ayah yang memberikan aturan untuk jam malam ketika anak sedang pergi keluar dengan teman-temannya serta memantau kegiatan anak misalnya meminta ijin yang jelas kepada ayah ketika hendak pergi dengan temannya dan meminta anak untuk memberi kabar jika pulang terlambat ke rumah. 
Bentuk keterlibatan ayah lainnya yang juga menonjol adalah engagement. Engagement merupakan bentuk interaksi langsung antara ayah dan anak melalui pengasuhan sehari-hari dan aktivitas yang dilakukan bersama oleh ayah dan anak. Contoh keterlibatan ayah dalam bentuk engagement adalah menghabiskan waktu bersama anak seperti bermain bersama, mengajarkan sesuatu kepada anak, atau terlibat dalam percakapan bersama. Dalam hal ini bentuk keterlibatan ayah pada remaja dapat ditampilkan dengan bagaimana cara ayah meluangkan waktunya untuk bisa melakukan interaksi ataupun berdiskusi dengan remaja ketika berada di rumah atau di luar rumah. Ayah yang berusaha memanfaatkan waktu untuk melakukan interaksi langsung dengan remaja dan dilakukan secara konsisten akan memunculkan kenyamanan dan keterbukaan pada remaja ketika akan bercerita kepada ayah. Misalnya ketika ayah sudah terbiasa mengobrol dengan remaja, maka remaja juga akan cenderung memiliki kebiasaan untuk selalu bercerita tentang apapun yang dialami remaja, baik itu pengalaman yang baik ataupun buruk. Dalam hal ini, remaja akan banyak mendapat pengetahuan baru serta respon yang didapat dari hasil interaksinya dengan ayah dan belajar memahami bagaimana menyikapi suatu masalah yang terjadi. Dengan demikian, pengendalian diri remaja dalam hal emosi akan lebih terkendali. Hal ini sejalan dengan penelitian yang dilakukan oleh McDowell dan Parke (2005) yang menunjukkan bahwa respon positif dari ayah pada pengalaman yang mengecewakan yang dialami oleh remaja dapat membantu mereka untuk lebih menerima kejadian yang terjadi. Dengan kata lain, ayah memiliki peran sebagai pendukung bagi remaja untuk mengenali dan merespon emosi dengan tepat.

Selain itu, aspek kecerdasan emosional yang paling tinggi dimiliki oleh remaja berdasarkan hasil analisis data yang telah dilakukan adalah aspek motivasi diri. Menurut Goleman (2007) motivasi diri berkaitan dengan pengendalian diri emosional, yaitu kemampuan seseorang untuk menahan diri dalam melakukan sesuatu. Motivasi diri dalam kecerdasan emosional menjelaskan bahwa dengan kemampuan motivasi diri yang dimiliki, individu akan cenderung memiliki pandangan yang positif dalam menilai sesuatu yang terjadi. Dengan kata lain, motivasi diri berpengaruh terhadap keinginan remaja dalam menentukan sikap maupun berperilaku. Dalam hal ini, ayah dapat menjadi role model remaja dalam berperilaku. Misalnya, apabila ayah suka memarahi anak dan bertindak keras, maka kemungkinan anak akan meniru perilakunya dan cenderung menyelesaikan masalah dengan kekerasan. Contoh tersebut menunjukkan bahwa perilaku ayah dalam pengasuhan dapat memberikan pengaruh bagi remaja dalam berperilaku baik secara positif maupun negatif.

Aspek kecerdasan emosional lainnya yang menonjol pada remaja adalah mengelola emosi. Mengelola emosi merupakan salah satu aspek yang berguna untuk membentuk kesadaran diri. Mengelola emosi melatih seseorang untuk mengontrol emosinya sehingga tidak lepas kendali. Menurut Goleman (2007) individu yang mampu mengelola emosi dengan baik akan terlihat dari cara mereka untuk memotivasi diri dan bangkit dari permasalahan yang dialami, sehingga apabila remaja dihadapkan pada situasi atau masalah mereka akan mampu untuk mengatasinya dengan bangkit dari tekanan yang ada dan berusaha mencari penyelesaian terbaik dalam permasalahannya. Hal tersebut dapat membuat remaja menjadi sosok yang tidak mudah menyerah akan sesuatu. Hal ini sejalan dengan penelitian Gottman \& De Claire (2003) yang menjelaskan bahwa individu yang mampu mengenali dan mengelola emosinya akan terlihat lebih percaya diri dan sehat secara fisik. Selain itu, individu juga akan cenderung menjadi orang dewasa yang sehat secara emosional. Individu yang memiliki kecerdasan emosional akan lebih terampil dalam mengendalikan emosinya sendiri ketika emosi tersebut muncul.

Berdasarkan pemaparan di atas menunjukkan bahwa ayah yang terlibat dalam pengasuhan memiliki hubungan dengan perkembangan kecerdasan emosional anak yaitu sebagai panutan bagi anak dalam mempelajari hubungan sosial dan mampu memahami diri sendiri, merespon sikap serta perilaku orang lain. Selain itu, keterlibatan ayah dalam pengasuhan pada praktiknya memberikan dampak positif 
terhadap aspek perkembangan anak, diantaranya yaitu perkembangan kognitif, emosi, sosial, dan penurunan perkembangan anak yang negatif.

\section{S I M P U L A N}

Kesimpulan dari hasil penelitian ini bahwa terdapat hubungan yang signifikan antara persepsi keterlibatan ayah dalam proses pengasuhan dengan kecerdasan emosional pada remaja. Arah hubungan antar keduanya yaitu positif, sehingga semakin tinggi remaja mempersepsikan keterlibatan ayah dalam proses pengasuhan, maka semakin baik kecerdasan emosional yang dimiliki. Sebaliknya, semakin rendah persepsi remaja terhadap keterlibatan ayah dalam proses pengasuhan, maka semakin rendah pula kecerdasan emosional yang dimiliki remaja.

Saran bagi ayah, diharapkan dapat meningkatkan keterlibatannya dalam pengasuhan anak. Bentuk keterlibatan ayah yang dapat dilakukan seperti memberikan kasih sayang serta perhatian yang konsisten dan berkelanjutan, menjadi model bagi anak, mendisiplinkan anak serta ayah juga memiliki kewajiban untuk menyediakan kebutuhan dasar bagi anak. Selain itu, untuk penelitian selanjutnya diharapkan dapat menghindari pilihan jawaban netral dalam penggunaan skala alat ukur. Hal tersebut guna menghindari adanya jawaban aman dari partisipan yang mengisi kuesioner.

\section{U C A P A N T ER I M A KASIH}

Penulis ucapkan terimakasih kepada Allah SWT, keluarga, sahabat, teman-teman beserta orang-orang spesial yang telah banyak membantu dan mendukung penulis dalam menyelesaikan penelitian ini.

\section{DEKLARASI POTENSI TERJADINYA KONFLIK KEPENTINGAN}

Wiwid Nur Islami dan Nur Ainy Fardana N. tidak bekerja, menjadi konsultan, memiliki saham, atau menerima dana dari perusahaan atau organisasi manapun yang mungkin akan mengambil untung dari diterbitkannya naskah ini.

\section{PUSTAKA ACUAN}

Agung, D. B., \& Matulessy, A. (2012). Kecerdasan emosi, kecerdasan spiritual, agresivitas pada remaja. Persona Jurnal Psikologi Indonesia, 99-104.

Allen, S., \& Daly, K. (2007). The Effect of Father Involvement: An Updated Research Summary of The Evidence Inventory. Canada: University of Guelph.

Asghari, M. S., \& Besharat, M. (2011). The relation of perceived parenting with emotional intelligence. Procedia - Social and Behavioral Sciences, 231-235.

Azwar , S. (2012). Metode Penelitian. Yogyakarta: Pustaka Belajar.

Damhuri, E. (2018, Februari 05). Mengapa ada siswa brutal kepada guru? Retrieved November 15, 2020, from

Republika.co.id:

Buletin Riset Psikologi dan Kesehatan Mental (BRPKM)

2021, Vol. 1(1), 317-326 
https://www.republika.co.id/berita/kolom/wacana/18/02/04/p3mv8b440mengapa-adasiswa-brutal-kepada-guru

Dewi, S., \& Kristiana, I. F. (2017). Hubungan antara persepsi keterlibatan ayah dalam pengasuhan dengan kecerdasan emosional pada siswa laki-laki kelas x SMK Negeri 4 Semarang. Jurnal Empati, 6(4), 107-111.

Finley, G. E., \& Schwartz, S. J. (2004). The father involvement and nurturant fathering scales: restrospective measures for adolescent and adult children. Educational dan Psychological Measurement, 143-164.

Goleman, D. (2007). Emotional Intelligence: Mengapa EI Lebih Penting Daripada IQ. Jakarta: PT. Gramedia Pustaka Utama.

Goleman, D. (2009). Emotional Intelligence: Why It Can Matter More Than IQ? London: Bloomsbury Publishing.

Gottman, J., \& De Claire. (2003). Kiat-Kiat Membesarkan Anak yang Memiliki Kecerdasan Emosi . Jakarta: PT Gramedia Pustaka Utama.

Guswani, A. M., \& Kawuryan, F. (2011). Perilaku agresif pada huntemahasiswa ditinjau dari kematangan emosi. Jurnal Psikologi Pitutur, 1(2), 86-92.

Handayani, W., \& Kustanti, E. R. (2018). Hubungan antara persepsi terhadap keterlibatan ayah dalam pengasuhan dengan intensi perilaku seksual pranikah pada remaja. Jurnal Empati, 7(1), 188194.

Hardanti, R. (2020). Kecerdasan Emosional Remaja Ditinjau dari Jenis Kelamin. Skripsi. Yogyakarta: Fakultas Keguruan dan Ilmu Pendidikan, Universitas Sanata Dharma.

Hidayati, K. B., \& Farid, M. (2016). Konsep diri, adversity quotient dan penyesuain diri pada remaja. Persona Jurnal Psikologi Indonesia, 137-144.

Hunter, E., Katz, L., Shortt, J., Davis, B., \& et al. (2011). How do I feel about feelings? emotion socialization in families of depressed and healthy adolescents. Journal Youth Adolescence, 428-441.

Hurlock, E. B. (2004). Psikologi Perkembangan: Suatu Pendekatan Sepanjang Rentang Kehidupan. Jakarta: Erlangga.

Lamb, M. E. (2010). The Role of Father in Child Development Fifth Edition. New York: John Willey \& Sons Inc.

Matthews, G., Zeidner, M., \& Roberts, R. D. (2002). Emotional intelligence: Science and myth. Cambridge: MA: Massachusetts Institute of Technology.

Mayer, J., Salovey, P., \& Caruso, D. (2008). Emotional intelligence: new ability or eclectic traits? American Psychological Association, 503-517.

McDowell, D., \& Parke, R. (2005). Parental control and affect as predictors of children's display rule use and social competence with peers. Social Development, 14(3), 440-457. 
Neuman, W. L. (2007). Basic of social research qualitative and quantitative approach. Massachusetts: Pearson Education Inc.

Pacheco, N. E., \& Berrocal, P. F. (2004). The role of students' emotional intelligence: empirical evidence. (2), 6.

Partasari, W. D., Lentari, F. R., \& Priadi, M. A. (2017). Gambaran keterlibatan ayah dalam pengasuhan anak usia remaja. Jurnal Psikogenesis, 159-167.

Pratama, A. (2018, Juli 23). KPAI Catat 161 Kasus Kekerasan Anak di Bidang Pendidikan Selama 2018. Retrieved November 15, 2020, from iNews.id : https://www.inews.id/news/read/189701/kpai-catat-161-kasus-kekerasan-anakdi-bidangpendidikan-selama-2018

Puspitorini, D. A. (2016). Hubungan Antara Persepsi Keterlibatan Ayah dalam Pengasuhan dengan Perilaku Kenakalan Remaja (Juvenile Delinquency) pada Laki-Laki. Skripsi. Tidak diterbitkan. Surabaya: Fakultas Psikologi, Universitas Airlangga.

Santrock, J. W. (2014). Adolescence. New York: McGraw-Hill Education.

Setyawati, \& Rahardjo, P. (2015). Keterlibatan ayah serta faktor-faktor yang berpengaruh dalam pengasuhan seksualitas sebagai upaya pencegahan perilaku seks pranikah remaja di Purwokerto. Jurnal Psikologi Fakultas Psikologi Universitas Muhammadiyah Purwokerto, 35-55.

UNICEF. (2015, November 25). Kekerasan Terhadap Anak: Kini Saatnya Bertindak . Retrieved November 15, 2020, from UNICEF Indonesia: https://www.unicef.org/indonesia/id/media_24996.html

Wulandari, D. (2012). Gambaran kecerdasan emosional pada siswa smkn 1 Jakarta. Jurnal Penelitian dan Pengukuran Psikologi, 183-190.

Zeidner, M., Matthew, G., \& Roberts, R. (2009). What We Know About Emotional Intelligence: How It Aspects Learning, Work, Relationships, and Our Mental Health. Cambridge: MIT Press Books. 